\title{
Effect of Heat Treatment and Gamma Irradiation on In Vitro Protein Digestibility of Selected Millet Grains
}

\author{
M. Sujatha*, T.V. Hymavathi, K. Uma Devi, T.P. Pradeepa Roberts and \\ D. Praveen Kumar \\ Post Graduate and Research Centre, Professor Jayashankar Telangana State Agricultural \\ University, Hyderabad-500030, Telangana, India \\ *Corresponding author
}

\begin{abstract}
A B S T R A C T
Keywords

Heat treatment, Gamma irradiation, Millet grains.

Article Info

Accepted: 10 September 2017 Available Online: 10 November 2017

The present investigation was conducted to find out the effects of heat or irradiation combined with heat on in-vitro protein digestibility (IVPD).Sorghum, pearl millet, foxtail millet were used in the study. Whole (WC) and dehulled (DC) grains were treated either with heat $\left(170^{\circ} \mathrm{C}\right)$ or irradiation at $1.0 \mathrm{kGy} / 2.5 \mathrm{kGy}$ and stored for 90 days. There was a significant $(p<0.05)$ effect of treatments, storage and grain and their interactions with increase in IVPD. The IVPD in DC and WC was 54.86 and 52.16 percent, which were improved by irradiation combination treatment by 2.59 and 2.13 percent in DC and WC respectively. $2.5 \mathrm{kGy}$ dose had higher effect than $1.0 \mathrm{kGy}$ on IVPD. Among the grains studied foxtail millet has highest IVPD followed by sorghum and pearl millet. In dehulled grains the percent increase of IVPD was highest in Foxtail millet, followed by pearl millet and sorghum; in contrast it was highest in sorghum followed by pearl millet and foxtail millet in whole grains. With the decreasing content of protein there was an increasing percentage IVPD. During 90 days storage there was an increase of IVPD to an extent ranging from 3.1 to 5.0 percent.
\end{abstract}

\section{Introduction}

Irradiation is one of the processing technologies currently available for the inactivation of microorganisms, and it has proven successful in ensuring the safety and extending the shelf life of foods (Mahapatra et al., 2005). Irradiation is also recognised to cause fewer overall physical and sensory changes than cooking, freezing, or canning (Molins, 2001). As irradiation is a physical process, no external additives are involved. The irradiation process is, therefore, useful and desirable as an alternative in the preservation and processing of various fresh, perishable, and high-protein foods, with or without chemical additives or biological controls (Lochhead, 1989 and Murray, 1990). During storage there may be some nutritional changes to the cereals, although for dry grains these changes will be small even over a period of several months. If grains are stored with a higher than ideal moisture content, grain and microbial amylases may begin to breakdown the starch, leading to a deterioration of grain quality. Several methods of drying are employed to reduce the moisture content to desirable levels. The effect of heating before irradiation is additive or slightly more than additive, ionizing 
radiation applied before heating is strongly synergistic in the inactivation of bacterial spores (Gombas and Gomez.,1978).High temperatures applied before radiation sensitize insects to radiation and hence allow the use of low dose (Tilton an Browser, 1987).

Gamma irradiation is capable of hydrolyzing chemical bonds, thereby leaving large molecules of starch into smaller fragments of dextrin that may be either electrically charged or uncharged as free radicals. Irradiation of gamma rays on bud wood can produce higher frequencies of mutation, leading to the creation of new variants compared to the control. Macronutrients (carbohydrates, proteins and lipids) content are relatively stable against irradiation doses up to $10 \mathrm{kGy}$, on the other hand, gamma irradiation affects proteins by causing conformational changes, oxidation of amino acids, rupturing of covalent bonds and formation of protein free radicals (Issa et al., 2011).

Contribution of millets to world cereal production is about $1 \%$, but their vital importance as food crops with respect to the agro-ecosystems is significant. The global millet production was about 27 million tons in 2009 (FAOSTAT, 2011). Digestibility may be used as an indicator of protein availability. It is essentially a measure of the susceptibility of protein to proteolysis. A protein with high digestibility is potentially of a better nutritional value than one of low digestibility, because it would provide more amino acids for absorption on proteolysis. The protein nutritional quality of food depends on content, digestion, absorption and utilization of amino acids (FAO, 1995).

\section{Materials and Methods}

Millet processing and heating was carried out at millet processing centre; grains were irradiated at irradiation unit of PJTSAU. The chemical analysis was conducted at the department of foods and nutrition, Post Graduate and Research centre of the university. Sorghum and foxtail millet grains were collected from RARS, Nandyal, ANGRAU and pearl millet from RARS, Palem, PJTSAU. All the grains were stored in polythene bags until used under dry and cool conditions away from insects and pests. The grains were dehulled in an abrasive dehuller (Gurunanak Engineering Co, Hyderabad) up to $17 \%$ removal of bran. In the present experiment electric rotary dryer (S K Engineering, New Delhi) was used which can be operated continuously for large quantity of grain.

\section{Grain treatment}

High moisture content of the grains is one of the factors for grain spoilage. The moisture content can be reduced by giving heat treatment. Many types of dryers can be used; however using rotary drier is more effective as there will be continuous agitation during drying providing uniform heat to all the grains. In the present experiment electric rotary dryer (S k Engineering, New Delhi) was used which can be operated continuously for large quantity of grain.

It has provision for adjusting the temperature and the rpm. Whole and dehulled grains of $5 \mathrm{~kg}$ all three millets were exposed to heat treatment at a temperature of $150-170^{\circ} \mathrm{C}$ for $1.5 \mathrm{~min}$ at $300 \mathrm{rpm}$.

Irradiation is one of the processing technologies currently available for the inactivation of microorganisms, and it has proven successful in ensuring the safety and extending the shelf life of foods (Mahapatra $e t$ $a l ., 2005)$. The millet grains were irradiated using cobalt - 60 gamma sources. Two different dosages $1.0 \mathrm{kGy}$ and $2.5 \mathrm{kGy}$ were 
used. Grains of $500 \mathrm{~g}$ were packed in polythene pouches and exposed to the irradiation.

\section{Procedure}

The in vitro protein digestibility of the samples was determined by enzymatic method. This was estimated according to the procedure of Singh and Jambunathan (1981). Known weight of the sample containing 6.75 mg nitrogen was taken and incubated with 5 $\mathrm{ml}$ of pepsin solution for $16 \mathrm{hrs}$ at $37^{\circ} \mathrm{C}$ and further incubated for $24 \mathrm{hrs}$ at $37^{\circ} \mathrm{C}$ with $2 \mathrm{ml}$ of pancreatin solution.2-3drops of toluene was added during incubation and the reaction was stopped by adding $20 \mathrm{ml}$ of $10 \%$ TCA. The suspension was centrifuged and supernatants were made up to $25 \mathrm{ml}$ of $5 \%$ TCA. An aliquot of $5 \mathrm{ml}$ was taken and evaporated to dryness at low temperature (80$90^{\circ} \mathrm{C}$ ) and Nitrogen content was determined by the micro Kjeldal procedure. Then digestive of each sample was calculated in the following way.

$I V P D=\frac{\mathrm{N} \text { in sample supernanats }-\mathrm{N} \text { in bank }}{\mathrm{N} \text { in starting materail, }} \times 100$

\section{Storage studies}

All the treated grains with a control samples of $500 \mathrm{~g}$ were stored for $30,60,90$ days in $\mathrm{HDPE}$ pouches at $34^{\circ} \mathrm{C}$ to $36^{\circ} \mathrm{C}$ of temperature and $23 \%$ of humidity. The estimations were done at the end of $30^{\text {th }}$ day, $60^{\text {th }}$ day and $90^{\text {th }}$ day.

\section{Study design}

The study was conducted using $3 \times 8 \times 4$ factorial design, which means 3 types of grains, 8 types of treatments and 4 levels of storage were used for the study. The effects of these factors were studied on in- vitro protein digestibility (Table 1).
All the results were statistically analyzed using IBM SPSS statistics 20 software. Multifactor ANOVA technique was used to test to find out the significant effect of treatments on IVPD of the millet grains (Table 2).

\section{Results and Discussion}

In the study whole and dehulled grains of Sorghum, Pearl millet and foxtail millet were used as controls to investigate the effects of heating and irradiation on in vitro protein digestibility. Within irradiation $1.0 \mathrm{kGy}$ and $2.5 \mathrm{kGy}$ dosages were used. Table 3 shows the IVPD of the millets. In untreated grains (control) the IVPD ranged from 48.23 to 54.85 percent with a significant difference $(\mathrm{p}<0.05)$. Pearl millet had significantly lower IVPD than those other two millets studied, which is in agreement with the studies of Elshazali et al., (2011) where the IVPD of the whole raw flour was 46.43 and $51.23 \%$ while that of the dehulled raw flour was 50.54 and $55.28 \%$ for Ashana and Dembi varieties of pearl millet. However the IVPD can be higher depending upon the varieties as shown by Hag et al., (2002), where IVPD of two different pearl millet cultivars were reported as 72.7 and 70.4 percent.

When the effect of treatment is considered maximum IVPD was observed in the dehulled grains $(54.86 \%)$ and least in the whole grain. This is due to the established fact that as the proportion of pericarp and germ material becomes less the IVPD improves (Duodu et al., 2002). Dehulling decreases the antinutrients that interfere with the IVPD.

Babiker and Eltinay (1993) also reported the improvement in IVPD is likely due to reduction in antinutrients during traditional treatments. High molecular weight polyphenols are known to precipitate proteins, reduce protein digestibility and produce off- 
coloured products (Hulse et al., 1980). Irradiation had higher effect on dehulled grains than on whole grains (Fig. 1). Irradiation had improved IVPD by 2.59 and 2.13 percent in DC and WC respectively. The pair wise comparisons revealed that there is no significant difference between DC and DEHE $(p<0.05)$. This indicates that heat treatment used in the present study had no adverse effect on IVPD. In contrast, IVPD in whole grain was found to have a significant improvement, where in the IVPD increased from 52.15pecent to 52.35 with heat treatment $(p<0.05)$. Hassan (2011) reported that all heat treatments significantly improved the IVPD of peanut seeds. Roasting in both brown and white sesame seeds partially eliminated the studied antinutrient and improved IVPD (increased by $10 \%$ and $9.1 \%$, respectively).

Irradiation combination treatment resulted in still higher IVPD i.e., $54.48 \%$ in WC and 57.46 in DC grains. Further it was also found that with increase of irradiation dosage from $1 \mathrm{KGy}$ to $2.5 \mathrm{kGy}$ there is an increase in the IVPD, suggesting that irradiation has beneficial effect on protein digestibility. Our results are in agreement with an earlier study (Fombang et al., 2005). An improvement of $12-18 \%$ was brought about in protein digestibility of sorghum porridge by irradiation of dry flour at $10 \mathrm{kGy}$. It is hypothesized that irradiation cleaved disulphide bonds in sorghum prolamin proteins, as observed by Koksel et al., (1998) for wheat, resulting in unfolding of protein structure. This would result in a more open protein network that would expose more protein sites to proteolytic enzymes, and hence improve digestibility. Sorghum prolamin proteins have a high content of disulphide bonds (Shull et al., 1991) and these can be cleaved by irradiation (Koksel et al., 1998). Splitting of these bonds by irradiation will no doubt modify protein structure. Shawrang et al., (2007) also reported that treatment of soybean meal and canola meal with gamma irradiation was successful in reducing degradation of protein by rumen microorganisms and increasing protein intestinal digestibility.

Table.1 The details of treatments used for the study

\begin{tabular}{|l|l|l|l|}
\hline Sno & Treatments (8) & Grains (3) & Storage period(4) \\
\hline 1 & Control -Whole grain & Sorghum & 0 Day \\
\hline 2 & Control- Dehulled grain & Pearl Millet & $30^{\text {th }}$ day \\
\hline 3 & Heat treated -Whole grain & Foxtail Millet & $60^{\text {th }}$ day \\
\hline 4 & Heat treated -Dehulled grain & & $90^{\text {th }}$ day \\
\hline 5 & Heat and 1.0kGy Irradiated -Whole grain & & \\
\hline 6 & Heat and 2.5kGy Irradiated - Whole grain & & \\
\hline 7 & Heat and 1.0kGy Irradiated -Dehulled grain & & \\
\hline 8 & Heat and 2.5kGy Irradiated - Dehulled grain & & \\
\hline
\end{tabular}


Table.2 ANOVA for the Effects of treatment, grain type and storage on in vitro-protein digestibility

\begin{tabular}{|c|c|c|c|c|}
\hline \multirow[t]{2}{*}{ Source } & \multirow[t]{2}{*}{$D F^{a}$} & \multicolumn{3}{|l|}{ IVPD $^{\mathrm{e}}$} \\
\hline & & $M S^{b}$ & $F^{c}$ & $P^{d}$ \\
\hline \multicolumn{5}{|c|}{ MAIN EFFECTS } \\
\hline Treatment $(\mathrm{T})$ & 7 & 104.089 & 73827.20 & 0.0000 \\
\hline Grain Type $(\mathrm{G})$ & 2 & 325.023 & 230529.94 & 0.0000 \\
\hline Storage $(\mathrm{S})$ & 3 & 44.0951 & 31275.41 & 0.0000 \\
\hline \multicolumn{5}{|c|}{ INTERACTIONS } \\
\hline TG & 14 & 2.98778 & 2119.15 & 0.0000 \\
\hline TS & 21 & 0.241051 & 170.97 & 0.0000 \\
\hline GS & 6 & 0.532923 & 377.99 & 0.0000 \\
\hline TGS & 42 & 0.165774 & 117.58 & 0.0000 \\
\hline
\end{tabular}

a- Degrees of Freedom, e- in vitro-protein digestibility

b - Mean Square,

c-F-Ratio, $d$ - $p$-value

Table.3 Effect of treatment, storage and grain type on in-vitro protein digestibility

\begin{tabular}{|l|l|}
\hline Effects & IVPD (\%) \\
\hline Treatment & \\
\hline DC & $54.8642^{\mathrm{b}}$ \\
\hline DEHE & $54.8667^{\mathrm{b}}$ \\
\hline DEHEI1.0 & 56.4796 \\
\hline DEHEI2.5 & 58.4558 \\
\hline WC & 52.1583 \\
\hline WHE & 52.3508 \\
\hline WHEI1.0 & 53.7783 \\
\hline WHEI2.5 & 55.19 \\
\hline Storage & \\
\hline 0 day & 53.6408 \\
\hline 30 ${ }^{\text {th }}$ day & 54.3835 \\
\hline 2th day & 55.2113 \\
\hline 3th day & 55.8363 \\
\hline Grains & \\
\hline Foxtail Millet & 56.2428 \\
\hline Sorghum & 55.8872 \\
\hline Pearl Millet & 52.1739 \\
\hline
\end{tabular}

*Significant at $\mathrm{p}=0.05$, values with similar superscripts are not significantly different with each other $(\mathrm{p}>0.05)$ 
Fig.1 IVPD (\%) of millets as affected by heat and irradiation combined with heat

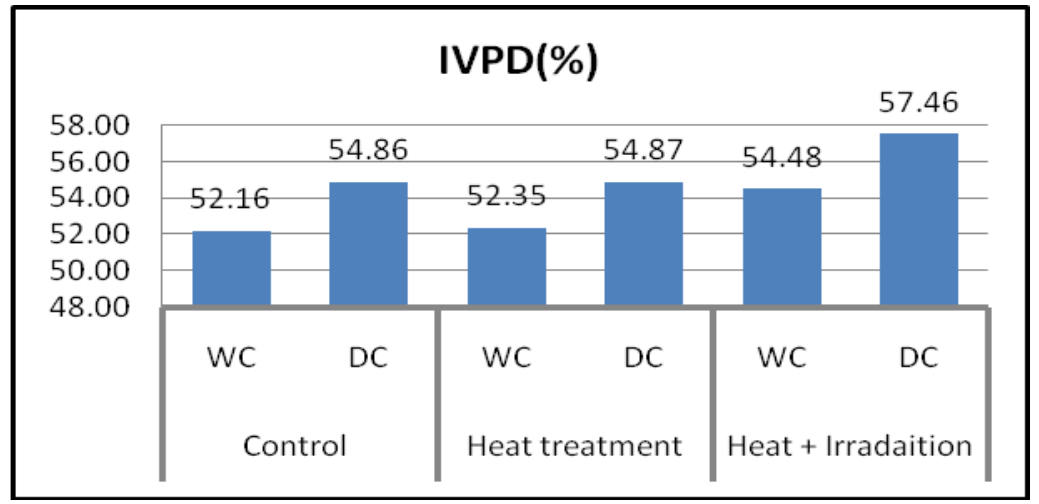

Protein digestibility of maize porridge was affected differently by irradiation compared to the two sorghum varieties. Digestibility decreased significantly in maize porridge made from wet-irradiated flour in comparison to porridge from unirradiated flour. Part of the reason could be the lower concentration of radiation-susceptible disulphide bonds in maize prolamin proteins (Duodu et al., 2002). When the effect of storage is considered the first significant increase was observed in the IVPD from zero days to 30 days and further significant improvement at 60 and 90 days. Improvement of IVPD due to irradiation compensates the reduction in protein content. The increase in IVPD in the present study and some earlier studies can be attributed to the hydrolysis of some protein into amino acid during storage. Similar observations were made by Sudesh Jood and Kapoor, (1992) in sorghum, wheat and maize storage.

Irrespective of treatments and storage, maximum IVPD was observed in foxtail grain followed by sorghum and pearl millet. The interaction effect of grain and treatment showed that the IVPD of the pearl millet is significantly lower than sorghum and foxtail millet. In the present study the pearl millet used was bio fortified grain for increased iron and zinc content. The interaction effect of storage and treatments revealed that DEHEI 2.5 samples had maximum IVPD at all the periods of storage.

The irradiation significantly improved the IVPD in both dehulled and whole grains. However the effect was more pronounced in dehulled grains $(2.58 \%)$ than in whole grains $(2.13 \%)$. Irradiation might have cleaved disulphide bonds in sorghum prolamin proteins, resulting in unfolding of protein structure giving more open protein network that would expose more protein sites to proteolytic enzymes, and hence improved digestibility. Heat alone did not improved IVPD in dehulled grains; however in whole grains there was a marginal yet a significant improvement. The first significant increase was observed in the IVPD from zero days to 30 days and further significant improvement at 60 and 90 days. Improvement of IVPD due to irradiation compensates the reduction in protein content.

\section{References}

Babiker, E.E and Eltinay, A.H.1993. Effect of reconstitution and $\mathrm{Na} 2 \mathrm{Co} 3$ on Tannin content and in vitro protein digestibility of faba bean cultivars. Plant Food for Human Nutrition.44: $119-130$.

Duodu, K.G., Nunes, A., Delgadillo, I., Parker, M.L., Mills, E.N.C., Belton, P.S and Taylor, J.R.N.2002. Effect of grain organisational structure and cooking on sorghum and maize in vitro protein digestibility. Journal of Cereal Science.35,161-174. 
ElShazali, A. M., Nahid, A. A., Salma, H. A and Elfadil, E. B. 2011. Effect of radiation process on antinutrients, protein digestibility and sensory quality of pearl millet flour during processing and storage. International Food Research Journal. 18(4),1401-1407.

FAO. 1995. Sorghum and Millets in human nutrition (FAO food and nutrition series, no 27). Food and agriculture organization of the united nations.

FAOSTAT. (2011). <http:www.faostat.fao.org/> Accessed 13-6-15.

Fombang, E.N., Taylor, J.R.N., Mbofung,C. M and Minnaar, F.A. 2005. Use of $\gamma$-irradiation to alleviate the poor protein digestibility of sorghum porridge. Food chemistry. 91, 695703.

Gombas, D.E and Gomez, R.F. 1978. Sensitization of Clostridium perfringens spores to heat by gamma radiation. Applied and Environmental Microbiology. 36(3), 403407.

Hag, M.E.E., Tinay, A.H.E and Yousif, N.E. 2002. Effect of fermentation and dehulling on starch, total polyphenols, phytic acid content and in vitro protein digestibility of pearl millet. Journal of Food Chemistry. 77:193196.

Hassan, E.S. E. 2011. Effect of Heat Treatments on Certain Antinutrients and in vitro Protein Digestibility of Peanut and Sesame Seeds. Food Science and Technology. 17 (1), 31 38.

Hulse, J.H., Laing, E.M and Pearson O.E. 1980. Sorghum and millets their composition and nutritive value Academic Press, New York.

Issa, P., Mehdi. B., Abolfazl. T and Mehdi. J. 2011. The use of gamma irradiation in agriculture. African Journal of Microbiology Research. 5(32): 5806-5811.

Koksel, H., Sapirstein, H. D., Celik, S and
Bushuk, W. 1998. Effects of gamma irradiation on wheat gluten proteins. Journal of Cereal Science. 28: 243-250.

Lochhead, C. 1989. The high-tech food process foes find hard to swallow. Food Technology. 43:56-59.

Mahapatra, A. K., Muthukumarappan, K., Julson, J. L. 2005. Applications of ozone, bacteriocins and irradiation in food processing. Food Science and Nutrition. 45(6), 447-461.

Molins, R.A.2001. Food irradiation: principles and applications. New York.

Murray, D.R.1990. Biology of food irradiations. New York.

Shawrang, P., Nikkhah, A., Zare-Shahneh, A., Sadeghi, A.A., Raisali, $G$ and MoradiShahrebabak, M. 2007. Effects of gamma irradiation on protein degradation of soybean meal. Animal. Feed Science Technology. 134:140-151.

Shull, J. M., Watterson, J. J and Kirleis, A. W. 1991. Proposed nomenclature for the alcohol soluble proteins (kafirins) of Sorghum bicolor (L. Moench) based on molecular weight, solubility and structure. Journal of Agricultural and Food Chemistry. 39: 83-87.

Singh, U and Jambunathan, R. 1981.Studies on desi and kabuli chickpea (Cicer arietimun L.) cultivars: levels of protease inhibitors, levels of polyphenolic compounds and in vitro protein digestibility. Journal of Food Science. 46, 1364-1367.

Sudesh, J and Kapoor, A.C. 1992. Effect of storage and insect infestation on protein and starch digestibility of cereal grains. Food Chemistry. 44,209-212.

Tilton, E.W and Brower, J.H.1987. Ionizing radiation for insect control in grains and grain products. Cereal Foods World. 32(2), 330335 .

\section{How to cite this article:}

Sujatha, M., T.V. Hymavathi, K. Uma Devi, T.P. Pradeepa Roberts and Praveen Kumar, D. 2017. Effect of Heat Treatment and Gamma Irradiation on In Vitro Protein Digestibility of Selected Millet Grains. Int.J.Curr.Microbiol.App.Sci. 6(11): 1014-1020. doi: https://doi.org/10.20546/ijcmas.2017.611.118 